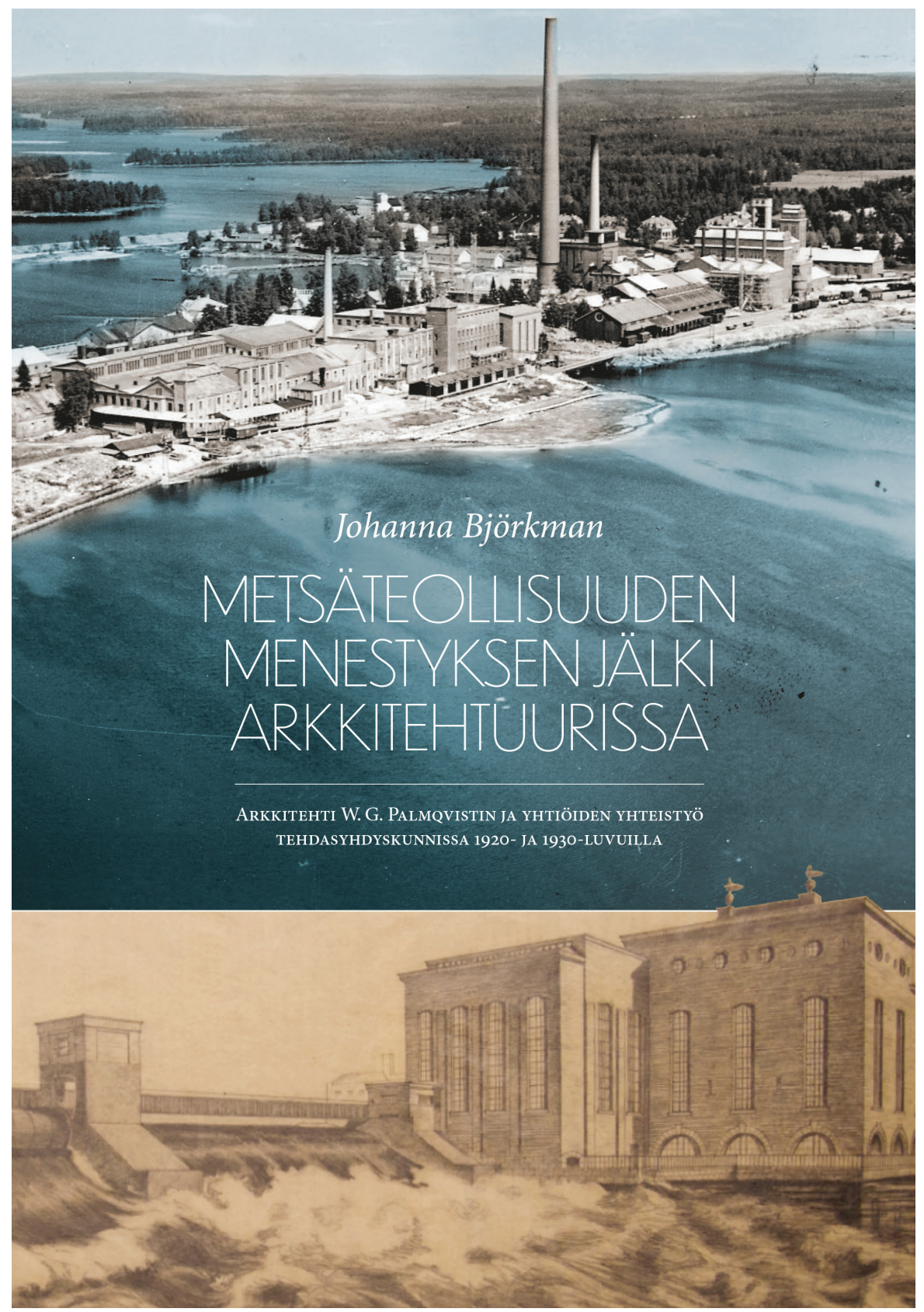

\title{
Metsäteollisuuden menes-
} tyksen jälki arkkitehtuurissa - Arkkitehti W. G. Palmqvistin ja yhtiöiden yhteistyö tehdasyhdyskunnissa 1920ja 1930-luvuilla

Johanna Björkman

Johanna Björkman, Metsäteollisuuden menestyksen jälki arkkitehtuurissa. Arkkitehti W. G. Palmqvistin ja yhtiöiden yhteistyö tehdasy hdyskunnissa 1920-ja 1930-luvuilla. Taidehistorian väitöskirja, Helsingin yliopisto, $234 \mathrm{~s}$. https://helda.helsinki.fi/handle/10138/300890

Metsäteollisuuden merkitystä on korostettu itsenäisen Suomen historiassa maamme kansantalouden perustana. "Suomi elää metsästä" on tuttu sanonta meille kaikille. Suomen itsenäistymisen ensimmäisinä vuosikymmeninä puunjalostusteollisuus nousi vientiteollisuuden kärkeen ja rakensi osaltaan suomalaisten taloudellista hyvinvointia. 
Metsäteollisuuden historiaa on käsitelty laajasti $\mathrm{mm}$. professori emeritus Markku Kuisman toimittamassa viisiosaisessa sarjassa Metsäteollisuuden maa. Tutkimushankkeen lähtökohtana oli kartoittaa, miten metsäteollisuus on vaikuttanut Suomen taloudelliseen, yhteiskunnalliseen ja poliittiseen kehitykseen. Lainaan Kuismaa: "[-] metsäteollisuus on edelleen keskeinen suomalaista yhteiskuntaa, taloutta, luontoa, kulttuuria ja politiikkaa muovaava tekijä. Se joka haluaa tietää, mikä liikuttaa Suomea, sen on tiedettävä mikä liikuttaa metsäyhtiöitä." On myös todettu, että metsäteollisuus on edunvalvonnassaan osannut ja halunnut aina vedota isänmaan asiaan. Yhteiskunnassa se on ollut merkittävä poliittinen voima ja viimeisen sadan vuoden aikana jatkuvasti näköalapaikalla.

Metsäteollisuuden merkitys Suomen kansantaloudelle on edelleen suuri. Varsinaisia suuryhtiöitä on kolme ja ne ovat nykyään globaaleja monialayrityksiä. Media uutisoi näkyvästi niiden uusista investointihankkeista kuten biotuotetehtaista. Biotalous eli uusiutuvien luonnonvarojen kestävä kehitys ja käyttö on merkinnyt uusien tuotteiden kehittämistä puukuiduista esimerkiksi muovin korvaajiksi. Uudet käyttötavat ovat nykyajan uusia menestymisen keinoja perinteisen sellun ja paperin tuotannon lisäksi.

Metsäteollisuudella on ollut viimeisen sadan vuoden aikana merkittävä rooli teollisen toimintansa lisäksi myös rakentajana. Tutkimukseni käsittelee metsäteollisuusyhtiöiden rakennuttamien tehdasyhdyskuntien arkkitehtuuria 1920- ja 1930-luvuilla. Taloudellinen menestys on näkynyt visuaalisesti ja konkreettisestikin arkkitehtuurissa, kun yhtiöt ovat sijoittaneet pääomiaan uusiin tuotantolaitoksiin ja laajemmin tehdasyhdyskuntien rakentamiseen. Metsäteollisuuden historiaa on tutkittu sen kansallisen merkityksen vuoksi huomattavan paljon, mutta sen tuottaman rakennuskannan tutkimus on jäänyt vähäisemmäksi. Tarkastelin väitöskirjassani yhtiöiden suunnittelua ja rakentamista arkkitehdin ja tilaajien välisen yhteistyön näkökulmasta. Tutkimuksen päähenkilö oli arkkitehti Wäinö Gustaf eli W. G. Palmqvist (1882-1964), joka suunnitteli uransa aikana huomattavan määrän eri teollisuusyhtiöiden rakennuksia ja yhdyskuntien asemakaavoja. Hänet voi profiloida usean yhtiön luottoarkkitehdiksi, jonka ura kesti monessa yhtiössä useita vuosikymmeniä. Vaikka teollisuus oli Palmqvistin tärkein asiakas, ei häntä voi pitää pelkästään teollisuuden arkkitehtina. Etenkin 1910- ja 1920-luvuilla Palmqvist suunnitteli huomattavan määrän asuinrakennuksia Helsinkiin.

Tutkimukseni kuluessa katseeni kääntyi arkkitehdista myös kohti tilaajia, sillä arkkitehtimonografioissa on usein korostettu arkkitehdin työn taiteellista puolta ja nähty rakennukset valmiina objekteina, vaikka suunnitteluprosessiin liittyy olennaisesti yhteistyö. En ole siis keskittynyt yksinomaan arkkitehdin uraan, sillä mielestäni on ollut kiinnostavaa pohtia arkkitehtia rakentamisen prosessiin osallistuvana toimijana. Arkkitehdin taiteellinen asiantuntijuus oli syy saatuihin toimeksiantoihin. Tutkimuksessani käsittelen myös lyhyesti kahden asiantuntijan - arkkitehdin ja insinöörin - erilaista suunnittelukenttää ja näiden välisiä jännitteitä.

Tarkemman tutkimuksen kohteina ovat olleet tehdasyhdyskunnat Mänttä ja Myllykoski. Ne ovat molemmat tyypillisiä metsäteollisuuden vaikutuksesta syntyneitä yhdyskuntia. Paperiteollisuus sijoittui Suomessa rannikolle, hyvien kuljetusyhteyksien ääreen ja usein olemassa olevien sahalaitosten lähelle tai vaihtoehtoisesti sisämaahan, lähelle 
raaka-ainetta. Rautatieverkoston kehittyminen teki kuljetukset sisämaasta mahdollisiksi. G.A. Serlachius Oy:n tehtaat perustettiin Mänttään, Pirkanmaalle 1860-luvulla. Puuhiomosta toimintansa aloittanut yhtiö perustettiin käytännössä erämaahan. Sen sijaan Myllykosken tehtaat Kymenlaaksossa perustettiin Kymijoen ääreen, joka oli jo varhaisen teollisen toiminnan syntysijoja. Saman vesistön ääreen perustettiin myös Kuusankosken, Voikkaan ja Kymin paperitehtaat, jotka yhdistyivät suuryhtiö Kymin Osakeyhtiöksi vuonna 1904

Tehdasyhdyskunnat syntyivät usein yhden tehtaan ympärille. Monissa tapauksissa yhtiö otti vastuun työntekijöistä rakentaen paikkakunnalle asuntoja, koulun, kokoontumistiloja ja monessa tapauksessa myös kirkon. Varhaisia esimerkkejä teollisuuden yhdyskunnista Pohjoismaissa olivat kaivosteollisuuden yhdyskunnat ja 1500- ja 1600-Iuvuilta lähtien rautaruukit ja niiden muodostamat ruukkiyhteisöt. Tehdasyhdyskunnat ja tehdaskaupungit olivat kansainvälisesti tarkastellen tärkeä osa teollistumista, eivätkä ne ole vain Suomelle tyypillinen ilmiö. Tutkimukseni osoitti, että suomalaiset tehdasyhdyskunnat olivat niiden kansainvälisesti jo omana aikanaan tunnettujen nk. malliyhdyskuntien jälkeläisiä, jotka esiintyivät ensin Englannissa, Saksassa ja Ranskassa sekä Yhdysvalloissa. Esimerkiksi Cadburyn suklaatehtaan Bournville ja saippuatehdas Lever Brothersin Port Sunlight Englannissa olivat valistuneiden tehtailijoiden perustamat yhdyskunnat, joita mainostettiin "tehtaana puutarhassa". Nämä olivat tietoisesti suunniteltuja yhdyskuntia, joissa näkyi perustajan paternalistinen asenne työväestöä kohtaan. Malliyhdyskuntien suunnittelussa näkyivät monet yleisemmin kaupunkisuunnittelussa näkyneet ideaalit kuten puutarhakaupunkiaate tai kaupunkikuvan kauneuden ja yhtenäisyyden tavoittelu. Myös kaupunkiutopiat piirtyivät inanneyhdyskuntien esikuvien taustalla.

Mäntän ja Myllykosken suunnittelussa ja rakentamisessa on nähtävissä ihanneyhdyskunnan projekti monin tavoin. Vaikka rakentamisen mittakaava oli niissä monia esikuviaan vaatimattomampi, yhdistävät hyvinvointitoimenpiteet ja pyrkimys esteettisesti korkeatasoiseen arkkitehtuuriin ne kansainväliseen diskurssiin teollisuuden malliyhdyskunnista. On myös merkillepantavaa, että maaseudulle syntyneistä uusista metsäteollisuuden yhdyskunnista osa kehittyi yhtä suuriksi kuin ajankohdan pienimmät kaupungit Suomessa. Ne siis edustivat tavallaan kaupungistumista, vaikka hallinnollisista syistä ne eivät tilastojen valossa kohottaneet maan alhaista kaupunkilaistumisastetta. Tehdasyhdyskuntien ja niitä ympäröivän maaseudun elämä poikkesi monin tavoin toisistaan.

Yksi tutkimustuloksiani oli, että metsäteollisuuden tehdasyhdyskuntien rakentamiseen liittyi olennaisesti ohjattu rakentaminen, jossa arkkitehdille annettujen toimeksiantojen taustana oli tavoite saada aikaan oikeanlainen, esteettisesti laadukas ja kaunis yhdyskunta. Yhtiöt ymmärsivät vastuunsa ympäristön kasvattavasta merkityksestä työväestön suuntaan, mutta samalla myös vastuunsa elinympäristöstä ja teollisuuden vaikutuksesta lähiseutuun. Deutscher Werkbund, joka perustettiin vuonna 1907 saksalaisen muotoilun edistämiseksi ja taiteen ja teollisuuden liiton vahvistamiseksi, tunnettiin Suomessakin. Werkbundin piirissä kiinnitettiin huomiota huonosti suunnitellun teollisuusrakentamisen aiheuttamiin tuhoihin maalaismaisemassa. Teollisuus nähtiin tärkeänä voimana, ja yritysten sosiaalista ja esteettistä vastuuta korostettiin korkean laadun suh- 
teen toimisto- ja tehdasrakennusten suunnittelussa.

Suomessa teollisuusarkkitehtuuria käytettiin käsitteenä 1920-luvulta lähtien, joskin tehdasrakennukset nähtiin pitkään hyötyrakennuksina ja niillä oli siten matala status arkkitehtien suunnittelutehtävänä. Pikkuhiljaa teollisuusrakennuksista tuli keskeinen tekijä tuotannon prosessin suunnittelussa, mutta myös niiden merkitys ulospäin näkyvänä yhtiön symbolina tuli yhtä lailla tärkeäksi. Arkkitehtuuri muodostui yritysten identiteettitekijäksi.

Arkkitehti-tilaaja-suhde korostui tutkimusajankohtanani henkilökohtaisina suhteina ja siksi tarkastelin tutkimuksessani toimijoina myös yhtiöiden johtajia. Yhteiskunnan sosiaaliset verkostot metsäteollisuuden piirissä olivat tuon ajan Suomessa henkilöityneet pieneen joukkoon. Tällä ryhmällä oli huomattavaa vaikutusvaltaa yhteiskunnassa, ja toisaalta myös arkkitehtuurin ja hyvän maun määrittelijöinä. Tutkimuksessani arkkitehti W. G. Palmqvistin henkilökohtaiset suhteet G.A. Serlachius Oy:n toimitusjohtajaan, vuorineuvos Gösta Serlachiukseen (18761942) ja Yhtyneet Paperitehtaat Oy:n johtajaan, kenraali Rudolf Waldeniin (1878-1946) edustivat horisontaalista suhdetta, joka perustui molemminpuoliseen luottamukseen. Serlachius ja Walden ovat yrityshistorian legendaarisia hahmoja ja osin tunnetumpia aktiviteeteistaan yhtiöidensä toiminnan ulkopuolella. Palmqvistin arkkitehtuurinäkemys kävi tyylillisesti yksiin Serlachiuksen ja Waldenin käsitysten kanssa. Tilaajilta arkkitehtuuriosaaminen vaati myös kulttuurista pääomaa. Tutkimuksessani tarkastelin maun käsitettä sosiologi Pierre Bourdieun tarkoittamalla tavalla, jossa maku nähdään symbolisen vallan määrittelijänä. Maun voidaan nähdä eriyttävän eri yhteiskuntaluokkia ja osoittavan yhteiskunnan hierarkkisuuden. Tutkimuksessani metsäteollisuuden sotien välisenä aikana rakennuttama tehdasyhdyskuntien rakennuskanta edustaa bourdieuläisessä mielessä eliitin maun mukaista arkkitehtuurinäkemystä. Gösta Serlachiuksen ja Rudolf Waldenin arkkitehtuuriin liittyneet makukäsitykset olivat konservatiivisia ja klassismin ideaaleihin kiinnittyneitä. Yksinkertaistaen voi todeta, että modernin arkkitehtuurin torjuminen pitkään johtui kaiken radikaalin vastustamisesta yhdyskunnissa ja poliittisesta konservatismista, jonka lähtökohtana oli perinteisten arvojen puolustaminen.
Metsäteollisuuden kasvu näkyi suoraan myös rakennetussa ympäristössä: tehdasyhdyskunnissa investoinnit uusiin teollisuuslaitoksiin ja muuhun rakentamiseen olivat seuraus taloudellisesta menestyksestä. Samaan aikaan rakentamisen taustalla oli muita merkittäviä yhteiskuntapoliittisia syitä. Sisällissota oli kärjistynyt monilla metsäteollisuuden paikkakunnilla ja jätti näihin traagisen jälkensä vuosikymmeniksi. Yhtiöt pyrkivät palauttamaan yhdyskuntiin työrauhan sisällissodan jälkeen ja jatkamaan tuotantoa. Hyvinvointikapitalismi tarkoitti yhtiöille työväestön olojen parantamista $\mathrm{mm}$. asumisen keinoin ja erilaisten hyvinvointitoimenpitein avulla. Näillä parannuksilla työnantaja myös tähtäsi työvoiman pysyvyyteen ja sen kontrollointiin.

Tutkimuksessani tulee esille myös teollisuusperintöprosessi, jonka syntyyn ovat vaikuttaneet teollisuuden rakennemuutos ja nk. deindustrialisaatio eli teollisen yhteiskunnan rakenteiden purkautuminen. Vasta teollisen toiminnan loppuminen teki teollisuusrakennuksista koneineen ja laitteineen säilyttämisen ja suojelun kohteita, historiaa. Kulttuuriperintöprosessi lähti liikkeelle teollisuushistorian muistomerkkien 
hävittämisestä, uhkana näiden ympäristöjen tuhoutumisesta ja oli siten vastareaktio tälle muutokselle. Teollisuusperintöön liittyvä suojeludiskurssi ja hallinnolliset toimenpiteet teollisuusrakennusten sekä laajemmin teollisuusympäristöjen suojelemiseksi alkoivat meillä 1970-luvulla. Käänteentekevä tapaus oli Tampereen Verkatehtaan suojelukiista, joka lisäsi kansalaisten kiinnostusta ja arvostusta teollisuushistoriaa ja -rakentamista kohtaan ja toisaalta nosti teollisuusperinnön yleiseen keskusteluun. Teollisen toiminnan päättyminen johti siten teollisuusperinnön käsitteen syntymiseen ja vakiintumiseen, sillä teollisuusympäristöt eivät voineet olla perintöä teollisen toiminnan ollessa käynnissä.

Nykypäivänä teollisuusympäristöt näyttäytyvät osana urbaania transformaatiota ja sen suunnittelukäytäntöjä. Teollisuusperinnön ja uusien käyttöjen yhteensovittaminen ei ole aina helppoa, vaan suojelun ja muutoksen välinen ristiriita johtaa helposti konflikteihin. Konfliktit johtuvat toisaalta erilaisista diskursseista, joista jokaiseen liittyy omat käsitteensä, arvonsa ja tavoitteensa. Myös teollisuusympäristöjen uudelleenkäyttötavat ovat vaihtelevia aina rakennusten tiukasta suojelusta radikaaleihin muutoksiin saakka.
Ydinkysymyksenä on usein: kuinka paljon muutosta voidaan sallia, jotta teollisuusperinnön autenttinen ydin, sen integriteetti vielä säilyy? Teollisuusperinnön säilyttämisen puolesta argumenttina toimii sen käsittäminen alueen yksilöllisenä ja vetovoimaisena tekijänä. Ympäristöille on löydetty uusia käyttötapoja esimerkiksi turismin tarpeisiin, museoina ja muina kulttuuritiloina. Samaan aikaan uudempi suurteollisuus on kompleksisempi ja vaikeampi kohde teollisuusperintönä eivätkä sen esteettiset arvot ole samalla yhteisesti arvotettuja tai hyväksyttyjä.

Kultturiperintöprosessiin ja rakennussuojeluun liittyy aina olennaisesti arvottaminen. Sekä Mäntän että Myllykosken teollisuusympäristöt ovat molemmat nykyään arvotettuina valtakunnallisesti arvokkaiksi rakennetuiksi kulttuuriympäristöiksi (RKY 2009, Museovirasto). Metsäteollisuus on jättänyt niihin jälkensä ja esimerkiksi yhdyskunnan hierarkkinen järjestys on vielä luettavissa niiden rakenteesta. Toisaalta teollisuusperinnön arvot tai juridinen suojelu eivät yksin riitä alueiden ja rakennusten käytön turvaamiseksi.

Teollisuusmaisemat muodostuvat erilaisista kerrostumista, jotka kertovat niistä ajoista, jolloin rakentamiseen investoitiin erityisesti. 1920- ja 1930-luvuilla Mäntässä ja Myllykoskella rakennettiin enemmän kuin koskaan aiemmin: syntyi uusia tuotanto- ja voimalaitoksia korkeine savupiippuineen. Mäntän spriitehdas ja voimalaitos piippuineen ja Myllykoskella uusi hiomo ja vesivoimalaitos sekä paperitehdas olivat uusia monumentaalisia maamerkkejä maisemassa. Yhä näissä yhdyskunnissa on luettavissa se, miten teollisuus oli rakentamassa Suomea köyhästä maatalousyhteiskunnasta teollistuneeksi hyvinvointivaltioksi.

Metsäteollisuus tuotti maailmansotien välisenä aikana merkittävän rakennusperinnön Suomessa sijoittamalla kasvaneita pääomiaan rakentamiseen. Metsäteollisuuden valta-asema 1920- ja 1930-luvuilla näkyi arkkitehtuurissa. Rakentamisen taustalla eivät olleet pelkästään tuotannolliset syyt ja vaatimukset, vaan myös selvästi yhteiskuntapoliittiset syyt. Tutkimuksessani toin esille, miten arkkitehtuuri on väistämättä osa yhteiskunnallista muutosta ja sillä on yhteyksiä yhteiskunnallisiin prosesseihin. Valta-asemaa esitettiin myös monumentaalisella rakentamisella. Suomessa teollisuus oli merkittävä tekijä kansakunnan identiteetin synnyttämisessä ja sen vahvistamisessa. Teollisuuteen 
ja teollistumiseen liitetty identiteetti liittyi ensi sijassa yhteiskunnan modernisoitumiseen ja kansalliseen tarinaan modernista teollisuusvaltiosta. Edustusarkkitehtuurin ohella yhtiöt synnyttivät sosiaalisen asumisen käytäntöjä ja hyvinvointiyhteiskunnan sittemmin käyttöönottamia toimintoja.

\section{Viitteet}

1 Kuisma, Markku 2006 (2. korj. painos).

Metsäteollisuuden maa. 1, Metsäteollisuuden maa:

Suomi, metsät ja kansainvälinen järjestelmä 1620-

1920 (Helsinki: Suomalaisen Kirjallisuuden Seura,

13).
FT Johanna Björkman on rakennetun ympäristön ja arkkitehtuurin historiaan erikoistunut taidehistorioitsija. Hän työskentelee tutkijana Helsingin kaupunginmuseossa kulttuuriympäristö- ja rakennussuojeluasioiden parissa. 